\title{
Do trade unions in Central and Eastern Europe make a difference?
}

\section{Low coverage and greater fragmentation can limit the benefits of trade unions}

Keywords: trade unions, Central and Eastern Europe, collective bargaining, union density, industrial relations

\section{ELEVATOR PITCH}

Countries with strong industrial relations institutions and well-established social dialogue often perform well in terms of economic growth and social cohesion. The weak and fragmented bargaining and low levels of union coverage in Central and Eastern Europe (CEE) raise concerns about these countries' potential to maintain competitiveness, tackle demographic and macroeconomic challenges, and catch up with Western European economic and social standards. There is evidence that unions in CEE continue to protect their members and generate wage premiums, despite their institutional weaknesses.

\section{KEY FINDINGS}

\section{Pros}

( Collective bargaining in CEE is associated with higher wages, in particular among medium- and high-skilled workers.

๑ Trade unions in post-socialist countries were effective in protecting their members during the 2008-2009 economic crisis.

- The process of EU integration strengthened the social dialogue and the role of the remaining trade unions in many CEE countries.

† The increase in non-standard work may represent an opportunity for trade unions to strengthen their role and improve perceptions of unions among employees.

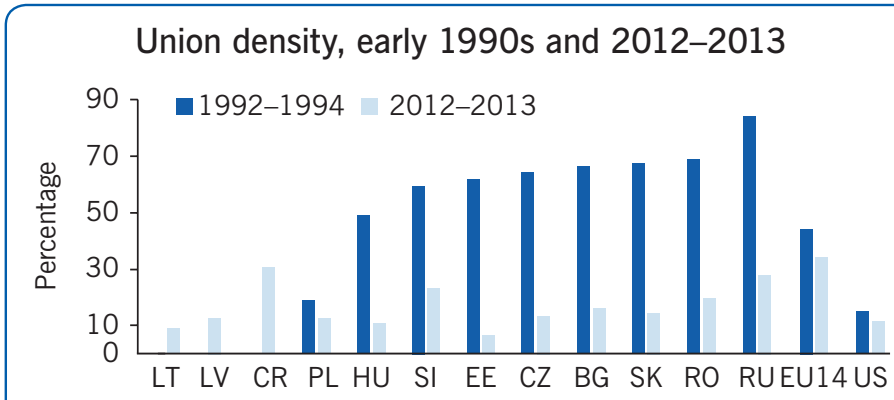

Note: EU14 refers to the 15 EU member states pre-2004, without Luxembourg.

Source: ICTWSS database (Visser 2016, version 5.1). Online at: http:// www.uva-aias.net/en/ictws; European Commission. Industrial Relations in Europe, 2014. I Z A

\section{Cons}

- Trade unions in CEE countries are weak and fragmented following a sharp decline in unionization during the period of economic transition.

- Collective bargaining coverage is low, taking place predominantly at the firm level and in the public sector.

- The increase in non-standard employment, which is rarely unionized, is lowering unions' coverage and bargaining power.

- CEE countries have diverse models of industrial relations, while the evidence regarding countries outside the EU is scarce.

\section{AUTHOR'S MAIN MESSAGE}

Although trade unions weakened substantially in CEE countries during the 1990s, there have been some signs of their revival since the 2000s. While unionization and collective bargaining coverage remain low, the wage premiums associated with collective bargaining have increased, and the surviving unions successfully protected their members during the 2008-2009 economic crisis. The institutional adjustments related to EU accession played a crucial role in strengthening unions. The unionization outlook is less clear, as several factors are further weakening unions' presence. Policy support for improving social dialogue and developing better industrial relations may benefit employees, employers, and the government. 


\section{MOTIVATION}

Trade union membership following the economic transition declined sharply in the great majority of Central and Eastern European (CEE) countries. The unionization rates in CEE are now lower than in most Western European economies. Moreover, collective bargaining coverage levels have decreased, and now cover a relatively small share of the workforce. Wage negotiations are largely decentralized, fragmented, and weakly coordinated. Overall, there is a general perception that trade unions are weak and ineffective-and thus irrelevant.

At the same time, however, there is some evidence of a revival of social dialogue in CEE countries, with the remaining unions playing a more substantial role in protecting workers and their wages in recent years. This article presents the mixed evidence that is currently available on the question of whether the CEE unions' bargaining power has increased, and on the potential drivers of, and explanations for, these trends.

\section{DISCUSSION OF PROS AND CONS}

\section{Trade union presence in Central and Eastern Europe}

The economies of the CEE countries experienced substantial declines in trade union membership in the aftermath of the economic transition of the late 1980s and the early 1990s. The decline in union density that occurred in these countries between the early 1990s and 20012/2013 was much steeper than the de-unionization that took place in Western Europe and the US during that period. As can be seen from the illustration on page 1, unionization in CEE is currently generally lower than in most EU14 countries, but higher than in the US. These trends mirror the transition from systems in which union membership was largely compulsory, to the neoliberal models most CEE countries adopted. The industrial relations that these systems established were not favorable for union development, as they provided for weak workers' protections and relatively low levels of social cohesion [1], [2]. The de-unionization went hand-in-hand with the expansion of private sector services and flexible labor contracts, where union coverage levels are traditionally low (also because workers have not been allowed to unionize, as in the case of bogus self-employment or, for example, civil-law-based contracts of mandate which became largely used in the previous decade in Poland).

Industrial relations in CEE are largely decentralized and fragmented, with collective bargaining taking place mainly at the local or firm level. Collective agreements cover much smaller shares of employees in CEE than in Western Europe, and these shares have continued to decline since the early 2000s in most CEE countries (Figure 1). Wage coordination (a measure that seeks to capture the degree of synchronization or integration of wage policy negotiations and implementation) is weak, and it is rare for collectively bargained terms to be extended to the uncovered sector. Employer organizations had to be created following the transition, which has proved to be difficult outside the (former) public sector. This has principally been the result of the fact that new employers have been small concerns, which are less likely to unionize, but also because of the general lower levels of trust and cooperation in post-socialist countries. As a result, employers' association membership is low: at around $30 \%$ in the new member states that joined the EU during 2004 and 2007, or around half of the corresponding levels in the pre-2004 EU15 countries [3]. 
Figure 1. Collective bargaining coverage since early 1990s

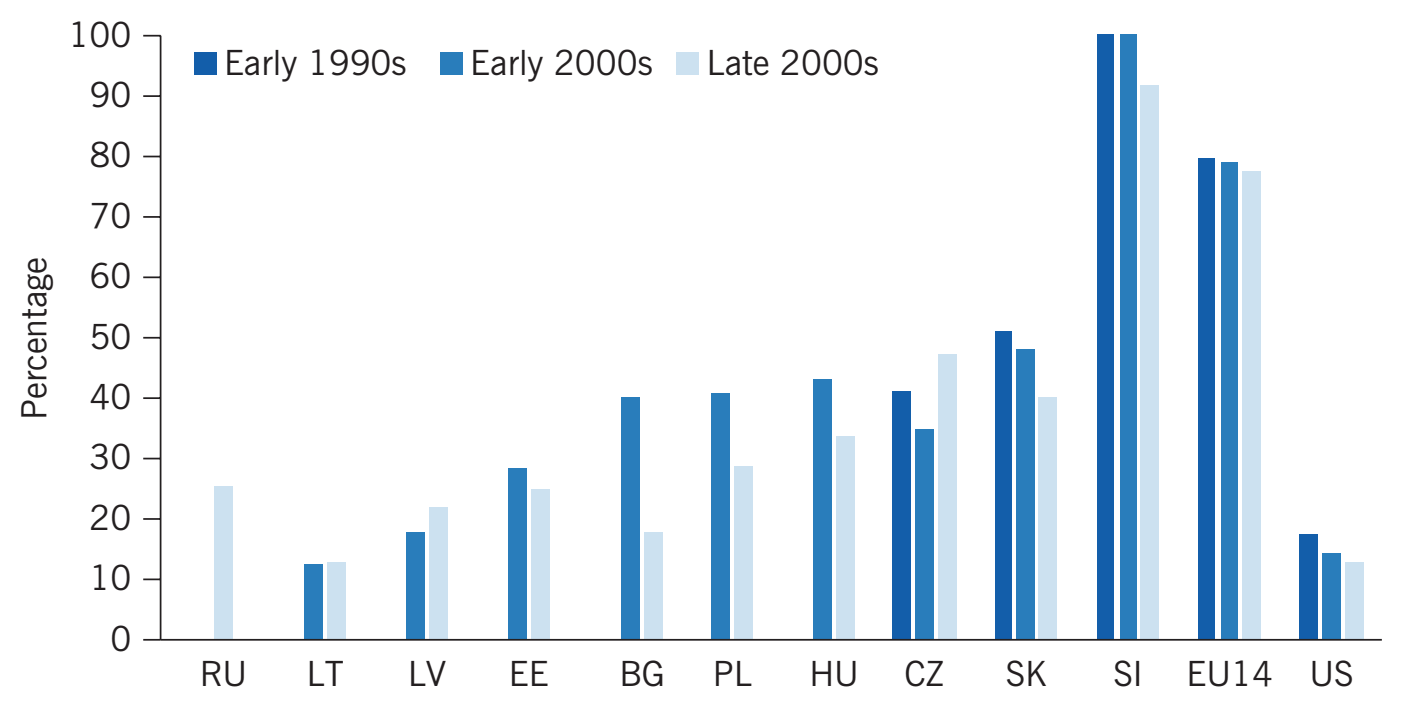

Note: EU14 refers to the 15 EU member states pre-2004, without Luxembourg.

Source: ICTWSS database (Visser 2016, version 5.1). Online at: http://www.uva-aias.net/en/ictws

Employers' organizations have also often been incapable of ensuring support from their members (in terms of time, money, and expertise) to support negotiations and to engage in policy dialogue [4]. This reflects the weakness of these organizations, their low coverage, and lack of trust in social dialogue in general. The bargaining that does occur takes place mainly in the public sector (collective agreements at the sectoral level mainly cover state enterprises and companies owned by the state treasury and, to a lesser extent, education and municipal workers), and is generally perceived as a meaningless affair [2]. Moreover, strike activity is much less intensive and less frequent in CEE countries than in most Western European states [3], [5]. This is mainly because such strikes are limited to public companies and services (utilities), as this is where unions manage to put pressure on the government and state as company owner. In the private sector there are only rare, local-level (workplace-based) industrial actions, with unions preferring to avoid confrontation.

Industrial relations in CEE are also very heterogeneous. Among the countries that are EU member states, union density is lowest in the Baltic states (7-13\%) and highest in the ex-Yugoslavian republics of Slovenia and Croatia (23\% and 31\%, respectively), though these levels are still below the EU14 average of 34\%. Russia's unionization level has also declined sharply, from more than $84 \%$ in the early 1990s to less than $30 \%$ in 2012 (see illustration on page 1). Slovenia has the most centralized and coordinated collective bargaining process in the region, with a national agreement for the public sector and a mixture of company and industry agreements in the private sector. Slovenia also has relatively high unionization rates, exceptionally high collective bargaining coverage levels (similar to those in the Scandinavian countries) (Figure 1), and a significant degree of state intervention in the collective bargaining process. Romania, Bulgaria, the Czech Republic, Slovakia, and Hungary have a mixture of sector- and company-level bargaining processes (with sectoral bargaining being particularly widespread in Romania and Slovakia [5]). Bulgaria and Romania stand out as having historically high levels of strike activity [3]. The 
industrial relations in the CEE countries (particularly those that joined the EU) continue to evolve and adapt to the changing economic conditions.

The failure of efforts to revive unions in the CEE region has been attributed to ideological, organizational, and structural issues that came to the fore in these countries during the post-communist era [2]. The perception of trade unions as being part of the "old regime" and the general distrust toward unions (the "ideological obstacle") is changing very slowly. Unions can also find it hard to gain a foothold in small private companies, which make up a larger share of CEE economies than in Western Europe (the "organizational obstacle"). Whether the strength of the Western European unions can be exported to post-socialist countries has also been questioned from the structural obstacle perspective, on the grounds that the CEE countries have highly liberal and flexible labor regimes [6] and high levels of workplace corruption (e.g. envelope payments, securing jobs with connections, or bribes) that tend to increase the asymmetry of employer and employee power-flexible and/or precarious workplaces are much less likely to be unionized and, like workplace corruption, can decrease workers' bargaining power. Trade unions in Russia have also been weakened by the lack of a stable, national-level alliance with a political party of the kind that exists in most other CEE countries [7].

\section{Unions in the CEE: Continuing to make a difference?}

The low levels of union presence observed in CEE countries do not necessarily imply that unions have no influence, as is often claimed. A number of recent studies have suggested that despite having low densities and low (and still falling) levels of bargaining coverage, the remaining unions in CEE have been improving the labor market outcomes of their members (in terms of wages and probability of employment retention), even during the Great Recession. Between 2002 and 2006 the wage premium from both firm- and industry-level agreements in the Czech Republic, Hungary, and Poland rose; although they differed across worker and firm types [8], [9].

Unions in post-socialist economies also turned out to be quite effective in protecting their members during the 2008-2009 economic crisis [10]. Members' job security was an important objective for unions in CEE countries during the financial crisis, as the sectorand firm-level bargaining processes in Slovakia, the Czech Republic, Poland, and Hungary demonstrated [5]. Unionized workers were less likely than other workers to lose their jobs, or have their wages delayed or suspended, especially in the countries that experienced a steeper decline in GDP (mainly the Baltic states, where GDP fell by approximately $15 \%$ in 2009). There is also evidence that trade unions helped union members keep their jobs by convincing employers to reduce employees' working hours or wages in lieu of laying them off. The economic downturn also elevated post-socialist unions' roles as legal "watchdogs" and welfare providers, in response to increased demand for their services during the crisis [11]. Provision of material support to union members, negotiated packages of additional support from the state to those laid off, or the fact that unions need to be consulted on (mass) redundancies, contributed to improving their image and perception by workers.

Employer organizations in CEE also fared rather well in the late 2000s, with their membership numbers remaining stable or even increasing. These trends ran counter to the developments observed in many Western European countries, many of which experienced a decrease in the number of employers' organizations, resulting from attempts to increase 
efficiency and create synergies [12]. The economic crisis also resulted in an increase in the density of employers' organizations in the Czech Republic, Slovenia, Estonia, and Latvia (among the EU member states in the east a decrease in density occurred only in Slovenia, which abandoned obligatory national agreements), though these densities remain very low, compared to the EU15.

It is possible that more effective unions are protecting a select, high-earning group of workers who differ from the traditional base of low-skilled, blue-collar workers they represented in the 1990s [2]. Workers in temporary jobs and other types of flexible or precarious employment are less likely to be unionized and, thus, protected [3]. The concession bargaining process in Hungary in the late 2000s resulted in unions accepting wage restraints in exchange for guarantees that the jobs of higher-skilled unionized workers would be protected. Meanwhile, temporary and unskilled workers were excluded from these negotiated responses [5]. There is evidence of a collective bargaining wage premium arising among medium- and high-skilled workers [8]. It is also worth noting that even though public sector employees have higher unionization and collective bargaining coverage rates than private sector workers, they were not necessarily better protected in the crisis. For instance, public sector employees had their wages frozen for several years in a row, despite unions' protests.

Overall, the CEE countries clearly have low levels of union density and of collective bargaining coverage, relative to both their early transition levels and the levels in Western European countries. There is, however, some evidence-albeit still scarce and incompletethat the surviving unions have managed to generate positive outcomes for their members, and that their influence has been increasing since the early 2000 s.

\section{What factors strengthened the remaining unions in the CEE?}

There are several factors that likely contributed to the increase in the bargaining power of the remaining trade unions in CEE. Arguably, the EU accession in 2004 and the institutional adjustments that preceded it had the greatest effects. This process strengthened (or revitalized) social dialogue and other parts of the institutional framework that influence wage setting in these countries (e.g. working time arrangements), thereby enhancing unions' wage bargaining power. Policymakers in these countries became more engaged with social partners when making regulatory adjustments to their labor markets as part of the EU integration process. For example, policymakers became actively involved in the Open Method of Coordination, a process of discussion and practice exchange through which the EU seeks to influence the member states' employment and social policies. Participation in this process required CEE policymakers to engage in extensive consultations with social partners about the draft guidelines and the annual assessment by the European Commission. These interactions appear to have indirectly increased trade unions' levels of policy engagement and policy making know-how, which in turn boosted unions' bargaining power [9].

The EU institutions also contributed significantly to the establishment of tripartite structures and practices (involving trade unions, employers' associations, and the government) in the new EU member states that were designed to stabilize the transformation process and strengthen the social consensus around it. These included social pacts or tripartite fora for social dialogue, following the necessity for the government 
to consult social partners on several areas of public policy, in particular those related to living standards. However, these structures have since been weakened, following changes in government attitudes toward trade unions and employer associations and bypassing them in the making of policy [12].

CEE countries also implemented a large number of legal reforms of, and amendments to, collective bargaining regulations, with the intention of stabilizing and adapting these rules to the requirements of the acquis communautaire (i.e. the accumulated legislation, legal acts, and court decisions that constitute the body of EU law). Shortly after the EU accession, CEE countries implemented the 2002 Directive on Information and Consultation of Employees relating to work councils, which provided both private and public organizations with a framework and minimum requirements for informing and consulting employees in the EU establishments. Although the work councils initially played a rather marginal role in the new EU member states' social dialogue, it is likely that they indirectly contributed to the empowerment of the unions. An increase in the power of labor inspections and changes in laws and enforcement mechanisms related to the minimum wage also improved unions' ability to negotiate and coordinate [9].

In addition to the EU accession process, there are several other factors that have strengthened unions in CEE after a long period of marginalization. These factors can help explain why unions have started ramping up their efforts to attract new members, particularly in the private sector. First, union officials can no longer afford to maintain unions with low membership numbers and correspondingly low financial contribution levels. Union leaders also have strong incentives to maintain their jobs, as they are unlikely to move to higher-ranked non-union jobs [2], principally because they are less ambitious than young, skilled workers. Second, there is an emerging international labor solidarity movement that strengthens unions' actions by promoting increased crossnational cooperation. Third, a new generation of workers, who are expressing more interest in unions and have a more favorable attitude toward unionization, are entering the labor market. Fourth, following the end of the post-communist era (characterized by restructuring, privatization, downsizing, and layoffs), unionists started shifting their goals and becoming increasingly interested in protecting their new base of members [2]. These conditions contrast sharply with those of the post-communist 1990s and early 2000s, during which periods union leaders were attempting to protect the jobs of mostly low-skilled workers whose labor was no longer needed by the newly privatized companies, and who for economic reasons would have been unable to keep their jobs in the long term.

Moreover, the rapid expansion of multinational companies contributed to the revitalization of CEE trade unions and collective bargaining. Most of the international companies that entered the CEE countries applied company-level industrial relations practices, similar to those used by their parent companies (mostly Western European ones), albeit adapted to local socio-economic conditions [9].

\section{The Great Recession and CEE unions}

During the Great Recession of 2008-2009, collective bargaining coverage levels decreased further in some of the CEE countries (Bulgaria, Hungary, Latvia, Romania, Slovakia, and Slovenia, all of which abandoned the national agreements in the private sector in 2005 [4], 
[12]). Company closures and employment losses contributed substantially to this decline in coverage, and were supported by the long-term trends of restructuring, outsourcing, and the shift away from manufacturing and toward services.

There is, however, evidence that the remaining unions were effective in protecting their members from the impact of the downturn. That effectiveness may have strengthened unions in post-socialist countries by improving perceptions of unions among nonmembers, which may in turn have encouraged new members to join [10]. There are also examples of cooperation between unions and employers during the crisis in the Visegrad countries (the Czech Republic, Slovakia, Hungary, and Poland) that resulted in new agreements being reached, mainly on working time flexibility [5]. The unions in the sectors in which the collective bargaining institutions are the most fragmented (or are even absent), such as the retail sector, are reportedly engaged in a range of initiatives (projects, common statements, joint declarations, and exchanges of information) [3]. CEE trade unions are also receiving increasing attention and support from their Western counterparts and partners. Several sectoral actions have been undertaken by social partners at the European level that target CEE countries, and include sectors such as banking, construction, woodwork, commerce, and education [3]. The aims of these actions are capacity-building and bringing social partners from the new member states into the sectoral social dialogue.

There has also been an increase in tripartite bargaining in most new EU member states. However, it has been reported that the 2009 crisis-related tripartite activity in Poland and Bulgaria did not translate into an overall improvement in the quality of social dialogue, at least at the national level [13]. The re-legitimization of social dialogue in Poland in the wake of the 2009 crisis (along with the intensive negotiations of the anti-crisis measures) resulted in the most comprehensive tripartite agreement since the 1990s being reached [13]. However, the working time agreements that were concluded did not spill over into other areas of collective bargaining (such as wages, holidays, or benefits); and the traditionally weak, multi-employer bargaining process (for groups of firms, occupations, or sectors, at local, regional, or central levels) became even weaker. Moreover, national coordination became more difficult given the divergent sectoral trends that emerged in the wake of the economic crisis. On the positive side, this revitalization of the social dialogue might have improved perceptions of trade unions and boosted their positions at the local level.

The crisis has also triggered reforms in the collective bargaining systems that may have strengthened unions' bargaining power in some CEE countries. Latvia's system for settling labor disputes, for instance, was reformed in 2008, thereby supporting and strengthening the existing mechanisms of conciliation, mediation, and arbitration. Croatia, Bulgaria, and Slovenia saw (usually modest) increases in the use of extension mechanisms (i.e. a situation when collective agreements negotiated between unions and employers' associations-one or more-are declared binding for firms that are not members of the initial agreement) that were rarely used before. The rules governing these mechanisms were eased in the Czech Republic, Estonia, Hungary, and Slovakia [12]. However, in some other countries bargaining was weakened during the crisis. Accordingly, in Romania representativeness rules made it practically impossible to conclude collective agreements above the company level. Also, the 2009 reform in Lithuania stipulated that collective agreements may provide less protection for employees than the levels of protection offered by the 2002 Labor Code in some areas, such as dismissal notice periods and severance pay. 


\section{LIMITATIONS AND GAPS}

The discussion in this article is limited first by the scarcity of studies asking the question "what do unions do in CEE countries?" and particularly by the dearth of studies that provide quantitative assessments of unions' impacts. The existing data and studies provide evidence of the weakness of industrial relations in CEE by noting the low coverage levels of unions, but provide relatively little information on the strengths and the influence of the remaining unions.

All of the studies presented are based on cross-sectional data, and the reported relationships between trade union membership and collective bargaining and employees' labor market outcomes cannot be interpreted as causal. Indeed, the causal effect of union membership or coverage on wages, or on the probability of job loss, is difficult to estimate because of the non-random process of becoming a member of a trade union or of a firm having a union wage agreement. The data are also limited in scope due to various unobserved characteristics that may play a role in wage setting.

Studies are further limited in their coverage of CEE countries. Most of the studies focus on the new EU member states that joined in 2004 and 2007. Finally, the post-socialist countries are very heterogeneous with respect to their models of industrial relations. This makes describing common patterns of change and their drivers challenging, and limits the adaptability of research results to other countries.

\section{SUMMARY AND POLICY ADVICE}

Trade unions are clearly weaker in CEE countries than in Western European countries. Union density and collective bargaining coverage levels are low in CEE, and unions continue to be seen primarily as obstacles to labor market flexibility and impediments to economic growth and job creation. However, there is evidence that these unions still manage to generate positive outcomes for their members. Moreover, there are some signs that the social dialogue is improving and that unions are recovering.

Despite the unfavorable conditions and legacies associated with unionization in this region, strengthening trade unions and collective bargaining in CEE could help tackle a number of challenges, including: (i) high levels of income inequality; (ii) demographic developments that could lead to labor shortages; and (iii) the growing incidence of nonstandard employment (temporary contracts, casual work, (dependent) self-employment, civil-law contracts, on-call work), which translates into diminishing budgetary revenues from social security contributions. The long-term economic consequences of these problems are largely absent from current political debates.

In light of the above challenges, support for improving social dialogue and developing better industrial relations may benefit employees, employers, and the government. This support could include bottom-up revitalization strategies for unions, helping to rebuild their capacity (such as worker education programs supporting organizing efforts, support for coalition building with other local agents, or creating international links). Many of the CEE social partners also expect that state intervention in collective bargaining will increase in the future [12], which could reinforce the position of this process. Policy support for union revival should also tackle the unresolved problem of the lack of access to trade 
unions among non-standard employees (such as those on contracts of mandate or in bogus self-employment).

\section{Acknowledgments}

The author thanks three anonymous referees and the IZA World of Labor editors for their many helpful suggestions on earlier drafts. Financial support from the Network for Jobs and Development initiative under the auspices of the World Bank is gratefully acknowledged. A previous study by the author (together with David Marsden and Simone Moriconi) contains a large number of background references for the material presented here, and has been used intensively in all major parts of this article [9].

\section{Competing interests}

The IZA World of Labor project is committed to the IZA Guiding Principles of Research Integrity. The author declares to have observed these principles.

(c) Iga Magda 


\section{REFERENCES}

\section{Further reading}

Meardi, G. Social Failures of EU Enlargement: A Case of Workers Voting with their Feet. London: Routledge, 2012.

Upchurch, M., R. Croucher, H. Danilovich, and C. Morrison. "The transformation of work and industrial relations in the post-Soviet bloc: 25 years on from 1989." Work, Employment \& Society 29:3 (2015).

\section{Key references}

[1] Bohle, D., and B. Greskovits. "Neoliberalism, embedded neoliberalism and neocorporatism: Towards transnational capitalism in Central-Eastern Europe." West European Politics 30:3 (2007): 443-466.

[2] Ost, D. "The end of postcommunism: Trade unions in Eastern Europe's future." East European Politics and Societies 23:1 (2009): 13-33.

[3] European Commission. Industrial Relations in Europe 2012. Luxembourg: Publications Office of the European Union, 2013.

[4] Visser, J. "What happened to collective bargaining during the great recession?" IZA Journal of Labor Policy 5:9 (2016).

[5] Glassner, V. "Central and eastern European industrial relations in the crisis: National divergence and path dependent change." Transfer: European Review of Labour and Research 19:2 (2013): 155-169.

[6] Crowley, S. "Explaining labor weakness in post-communist Europe: Historical legacies and comparative perspective." East European Politics and Societies 18:3 (2004): 394-429.

[7] Cook, L. Postcommunist Welfare States, Reform Politics in Russia and Eastern Europe. London: Cornell University Press, 2007.

[8] Magda, I., D. Marsden, and S. Moriconi. "Collective agreements, wages, and firms' cohorts: Evidence from Central Europe." Industrial and Labor Relations Review 65:3 (2012).

[9] Magda I., D. Marsden, and S. Moriconi. "Lower coverage but stronger unions? Institutional changes and union wage premia in Central Europe." Journal of Comparative Economics 44:3 (2016): 638-656.

[10] Ivlevs, A., and M. Veliziotis. "What do unions do in times of economic crisis? Evidence from Central and Eastern Europe." European Journal of Industrial Relations 23:1 (2017): 81-96.

[11] Croucher, R., and M. Rizov. "Union influence in post-socialist Europe." Industrial and Labor Relations Review 65:3 (2012): 630-650.

[12] Eurofound. Collective Bargaining in Europe in the 21st Century. Luxembourg: Publications Office of the European Union, 2015.

[13] Meardi, G., and V. Trappman. "Between consolidation and crisis: Divergent pressures and sectoral trends in Poland." Transfer 19:2 (2013): 195-204.

\section{Online extras}

The full reference list for this article is available from:

http://wol.iza.org/articles/do-trade-unions-in-central-and-eastern-europe-make-a-difference

View the evidence map for this article:

http://wol.iza.org/articles/do-trade-unions-in-central-and-eastern-europe-make-a-difference/map 